\title{
ANDROLOGY
}

\section{Study of Microdeletions in the Y Chromosome of Infertile Men With Idiopathic Oligo- or Azoospermia}

\author{
GUIMEI YAO, ${ }^{1}$ GUIAN CHEN, ${ }^{1,3}$ and TIANMING PAN ${ }^{2}$
}

Submitted: November 16, 2000

Accepted: May 31, 2001

\begin{abstract}
Purpose: To determine the relationships between idiopathic oligo- or azoospermia and microdeletions of the $Y$ chromosome.

Methods: Eighteen Y-linked sequence-tagged sites (STSs) in AZF (Azoospermia Factor) region were screened by means of multiplex PCR (Polymerase Chain Reaction) in 50 idiopathic infertile men, including 16 patients with azoospermia, 13 severe oligospermia, and 21 oligospermia.

Results: Microdeletions in the genomic DNA were observed in 8 of 50 cases, 3 with azoospermia, 1 severe oligospermia, and 4 oligospermia. Total deletion rate was $16.0 \%$ (8/50). The deletion regions were concentrated on $A Z F d$ and $A Z F c$.

Conclusions: Microdeletions of the $Y$ chromosome are an important cause for idiopathic oligo- or azoospermia. Multiplex PCR is a useful technique for detecting the microdeletions. To avoid transmission to their offspring, patients with idiopathic oligo- or azoospermia should be screened for microdeletions of the Y chromosome before ICSI treatment for infertility.
\end{abstract}

KEY WORDS: idiopathic oligo- or azoospermia; male infertility; multiplex PCR; Y chromosome microdeletion.

\footnotetext{
${ }^{1}$ Department of Obstetrics and Gynecology, The Third Hospital, Peking University, Beijing 100083, China.

${ }^{2}$ Department of Urology, The Third Hospital, Peking University, Beijing 100083, China.

${ }^{3}$ To whom correspondence should be addressed at Department of Obstetrics and Gynecology, The Third Hospital, Peking University, Beijing 100083, China; e-mail: guimei2613@yahoo.com.cn.
}

\section{INTRODUCTION}

Tiepolo and Zuffardi provided the first evidence that a major part of the long arm of the Y chromosome might be required for fertility in men when they karyotyped 1170 men and found that in six azoospermia men, most of the long arm of the Y chromosome were missing (1976) (1). Subsequently, it has been shown that the loss of the multiple DNA fragments in Yq11.23 region (Azoospermia Factor, AZF), including AZFa, AZFb, AZFc, and AZFd (the proximal AZFc) may lead to the failure of spermatogenesis in various degree and that several Y-linked genes, such as YRRM (YRRM1, YRRM2), DAZ, DFFRY, and DBY and others, are related to spermatogenesis $(2,3)$. It has been proved that deletions of AZF in azoospermia or oligospermia will be transmitted to male descendants by means of the intracytoplasmic sperm injection (ICSI) technique, that is provided since 1992 to couples suffering from severe forms of male factor infertility $(4,5)$. Therefore ICSI male offsprings with similar microdeletions of Yq, just like their father, may also suffer subsequent infertility when they become adults (6). Since gene candidates for AZF are multicopy, the screening of the gene deletion is complex (2). We selected 18 sequence tagged sites (STSs) linked to Yq11.23 in AZF region to screen microdeletions in idiopathic infertile men. By using multiplex polymerase chain reaction (PCR), we studied the relationships between the microdeletions of the Y chromosome and idiopathic infertile Chinese men. 


\section{MATERIALS AND METHODS}

\section{Patients}

Fifty men 25 to 40 years with idiopathic infertility for an average of 5.8 years, referred to the urology or IVF clinic of the Third Hospital of Peking University from Dec 22, 1999, to June 1, 2000, were studied. Medical, sexual, and family history, lifestyle, and habits of these men were recorded. After informed consent, peripheral blood samples were drawn from patients: 16 azoospermia, 13 severe oligospermia ( $<5$ million sperm $/ \mathrm{mL}$ ), and 21 oligospermia (5 million to $<20$ million sperm $/ \mathrm{mL})$. At least two semen analyses were done and the WHO criteria were used to evaluate the semen parameters. Testicular biopsies were performed in most infertile men with azoospermia. Anatomical abnormalities, such as vas deferens obstruction or varicocele, were excluded by physical examination. Follicle stimulating hormone (FSH), Luteinizing hormone (LH), and Testosterone (T) were measured by radioimmunoassay (Diagnosis
Products, USA). The hormone levels of the patients were within normal range $(\mathrm{FSH}<20 \mathrm{IU} / \mathrm{L}, \mathrm{LH}<$ $25 \mathrm{IU} / \mathrm{L}, \mathrm{T}$ 9.36-37.1 nmol/L). Standard Cytogenetic techniques of $\mathrm{G}$ banding were used to analyze karyotype (ISCN criteria).

\section{Screening for 18 Y-linked STSs}

Genomic DNA was extracted from peripheral blood lymphocytes by using Wizard Genomic DNA Purification Kit (Promega, USA).

The Y Chromosome Deletion Detection System, Version 1.1 was supplied by Promega. This system consists of 18 primer pairs which are homologous to previously identified and mapped STSs and that are separately located in AZFa, AZFb, AZFc, and AZFd regions of $\mathrm{Yq}$ (Fig. 1 -modified according to the figure of the technical manual of Promega). All primers were nonpolymorphic short DNA fragments grouped into four sets for use in multiplex PCR. This makes it possible to determine the presence or absence of all

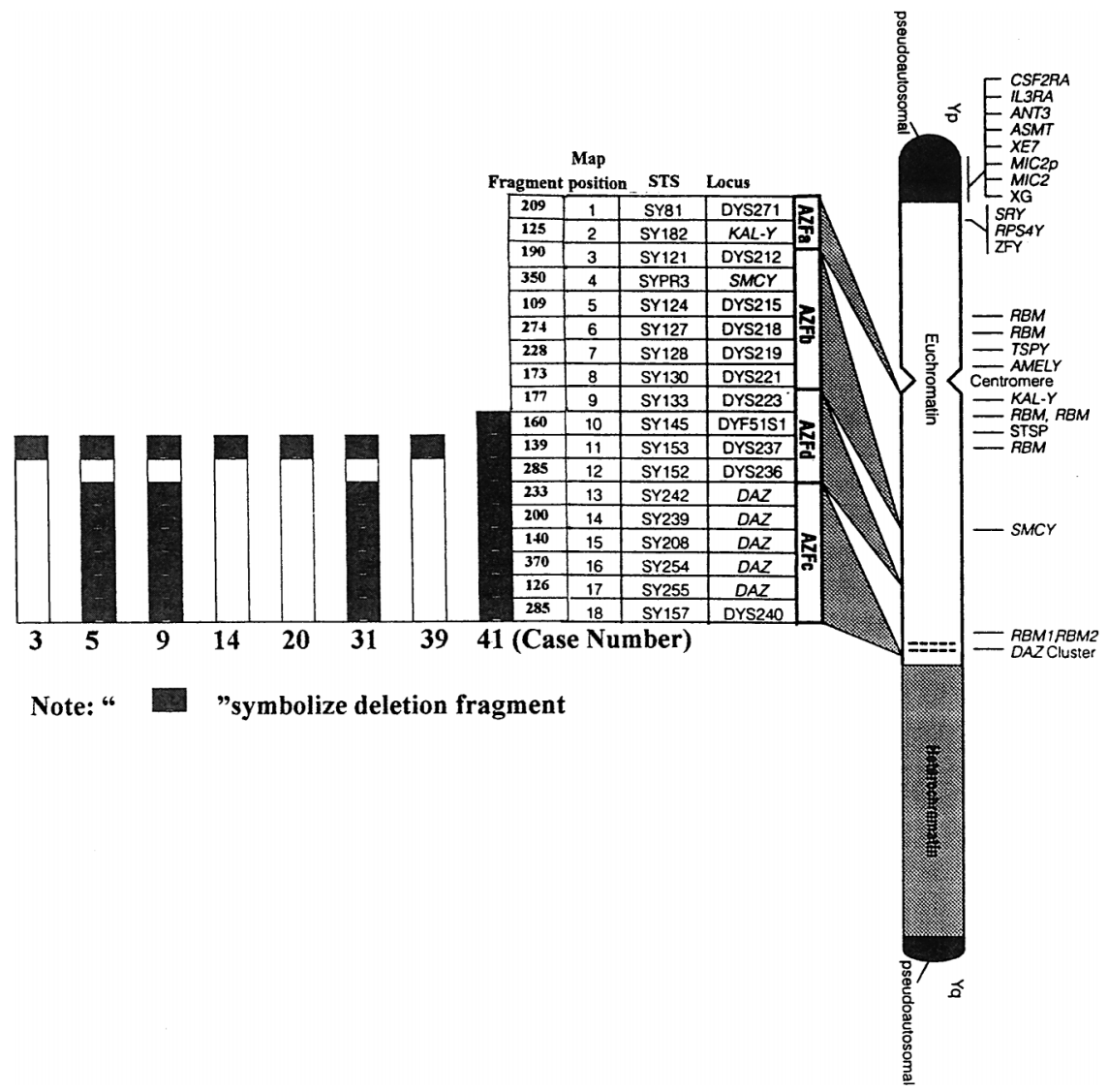

Fig. 1. 18 Sequence tagged sites in $\mathrm{Y}$ chromosome and 8 cases with deletion fragments. 
18 STSs by performing one times of PCR amplification and to identify Y chromosome deletions in these regions associated with male infertility. Each multiplex primer set contains a control primer pair that amplifies a fragment of the X-linked SMCX locus as an internal control for the amplification reaction and the integrity of the genomic DNA sample. In addition, with each PCR run, a normal male control provided by kits, a normal female control, and blank control were included. To avoid contamination, strict rules were taken, PCR compositions were prepared on a laminar flow hood and PCR products were examined in another room. The conditions for PCR were as follows: total reaction volume was $25 \mu \mathrm{L}, 50 \mathrm{ng}$ genomic DNA as a template, 1 IU Tag DNA polymerase and $20 \mu \mathrm{L}$ of each Master Mix A, B, C, or D which included primers, $\mathrm{Mg}^{++}$, buffer, and dNTP. The complete Mixes were placed directly in a thermocycler (MJ PTC-200) preheated to $94^{\circ} \mathrm{C}$ for $2 \mathrm{~min}$. Cycling conditions for 35 cycles were: $94^{\circ} \mathrm{C}$ for $1 \mathrm{~min}, 57^{\circ} \mathrm{C}$ for $30 \mathrm{~s}$, and $72^{\circ} \mathrm{C}$ for $1 \mathrm{~min}$. The final extension time was $5 \mathrm{~min}$, at $4{ }^{\circ} \mathrm{C}$ store. The $8 \%$ polyacrylamide gel electrophoresis (PAGE) was used to separate PCR products in $1 \times$ TBE buffer, and silver stain was used to visualize the bands amplified by PCR. Silver stain was used instead of ethidium bromide because the former is safer and more convenient than the latter for observation and photography.

\section{RESULTS}

Among 50 men with oligo- or azoospermia, a total of 8 cases were found to have deletions in the regions of $\mathrm{AZFd}$ and $\mathrm{AZFc}$. Deletions of $\mathrm{AZFd}$ (DYS237) + AZFc (DAZ region + DYS240) were found in 2 of the 16 men with azoospermia, 1 of the 13 men with severe oligospermia. For the other 1 of the 16 men with azoospermia, there were deletions of AZFd (DYF51S1 + DYS237 + DYS236) and AZFc (DAZ + DYS240) in the Yq. Among 21 oligospermia men, four had single deletion of AZFd (DYS237). Total deletion rate was $16.0 \%(8 / 50)$. The results are shown in Figs. 2 and 3, 8 cases with deletions are summarized in Table I.

\section{DISCUSSION}

This study showed microdeletions of the Y chromosome in 3 of the 16 men with azoospermia, 1 of the 13 with severe oligospermia, and 4 of the 21 with oligospermia. The frequency of deletions was much higher in the group of azoospermia (3/16) than that

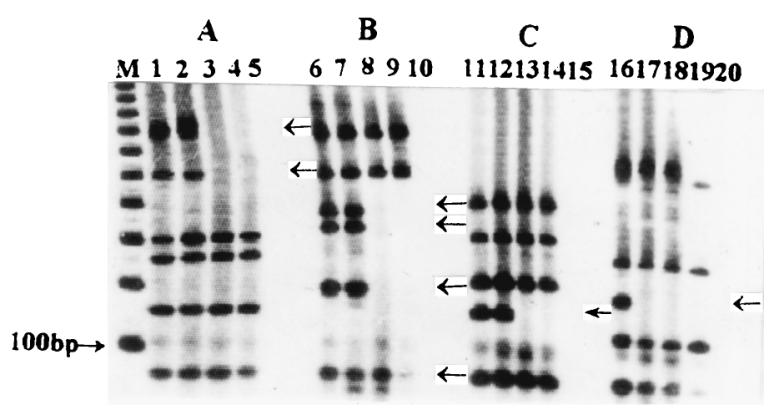

Fig. 2. Yq microdeletions detected by Multiplex PCR from cases 3, 5, and 9; Multiplex Master Mix A (lanes 1-5), Multiplex Master Mix B (lanes 6-10); Multiplex Master Mix C (lanes 11-15), Multiplex Master Mix D (lanes 16-20); Case 3 (lanes 2, 7, 12, 17), Case 5 (lanes 3, 8, 13,18), Case 9 (lanes 4, 9, 14,19) Positive control: lanes $1,6,11,16$, Negative control: lanes $5,10,15,20$. $\mathrm{M}$ is a marker of the $50 \mathrm{bp}$ DNA step ladder, arrows indicate the positions of Yq deletion.

of oligospermia (5/34). This proportion was consistent with those reported by Stuppia et al. (18.2\% for idiopathic infertility, $21 \%$ for azoospermia, and $14.2 \%$ for oligospermia) (7). Vogt obtained the average deletion rate of $10.18 \%$ and the total deletion rate was much higher in the idiopathic group than other causes (8). According to the different selection criteria for infertile men, the deletion rates had a wide range from 1 to $55 \%$ as reported previously. No deletions of DAZ were found in 700 normal men screened by Stuppia (7). As compared with other known causes of male infertility, we realized that the microdeletions of $\mathrm{Y}$ chromosome are relatively frequent within the idiopathic infertile men and the frequency increases with the severity of the spermatogenesis defect, but

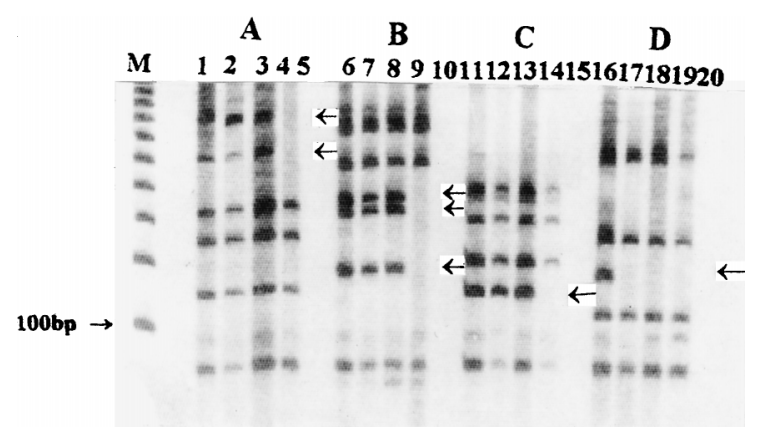

Fig. 3. Yq microdeletions detected by Multiplex PCR from cases 14, 20 and 31; Multiplex Master Mix A (lanes 1-5), Multiplex Master Mix B (lanes 6-10); Multiplex Master Mix C (lanes 11-15), Multiplex Master Mix D (lanes 16-20); Case 14 (lanes 2, 7, 12, 17), Case 20 (lanes 3, 8, 13, 18), Case 31 (lanes 4, 9, 14, 19); Positive control: lanes 1, 6,11, 16; Negative control: lanes 5, 10, 15, 20. $\mathrm{M}$ is a marker of the 50bp DNA step ladder, arrows indicate the positions of Yq deletion. 
Table I. Clinical and Cytogenetic Characteristics of 8 Patients With Y Chromosome Microdeletions

\begin{tabular}{|c|c|c|c|c|c|c|c|c|c|}
\hline \multicolumn{2}{|c|}{ Patient } & \multirow{2}{*}{$\begin{array}{c}\text { Duration of } \\
\text { infertility years }\end{array}$} & \multirow{2}{*}{$\begin{array}{l}\text { Sperm count } \\
\left(\times 10^{6} / \mathrm{mL}\right)\end{array}$} & \multirow{2}{*}{$\begin{array}{c}\text { Testicular } \\
\text { biopsy }\end{array}$} & \multirow[b]{2}{*}{ Deletion } & \multicolumn{3}{|c|}{ Hormone } & \multirow[b]{2}{*}{ Karyotype } \\
\hline No & $\overline{\text { Age }}$ & & & & & $\overline{\mathrm{FSH}(\mathrm{IU} / \mathrm{L})}$ & LH (IU/L) & $\mathrm{T}(\mathrm{nmol} / \mathrm{L})$ & \\
\hline 3 & 32 & 4 & $8-15$ & No biopsy & DYS237 & 6.20 & 7.30 & 12.79 & $46, X Y$ \\
\hline 5 & 27 & 4 & $<0.01$ & No biopsy & $\begin{array}{l}\text { DYS237 } \\
\text { DAZ } \\
\text { DYS240 }\end{array}$ & 3.20 & 8.50 & 9.36 & $46, X Y$ \\
\hline 9 & 38 & 12 & 0 & $\begin{array}{l}\text { Severe } \\
\text { HSG } \\
\text { SGA }\end{array}$ & $\begin{array}{l}\text { DYS237 } \\
\text { DAZ } \\
\text { DYS240 }\end{array}$ & 6.40 & 13.5 & 14.21 & $46, X Y$ \\
\hline 14 & 40 & 10 & $15-18$ & No biopsy & DYS237 & 3.8 & 6.7 & 9.36 & $46, X Y$ \\
\hline 20 & 32 & 7 & $3.7-12$ & No biopsy & DYS237 & 3.7 & $<3$ & 11.3 & $46, X Y$ \\
\hline 31 & 25 & 3 & 0 & $\begin{array}{l}\text { Severe } \\
\text { HSG } \\
\text { SGA }\end{array}$ & $\begin{array}{l}\text { DYS237 } \\
\text { DAZ } \\
\text { DYS240 }\end{array}$ & 13.8 & 11.1 & 16.1 & $46, X Y$ \\
\hline 39 & 27 & 5 & $17-19$ & No biopsy & DYS237 & 2.3 & 1.32 & 15.3 & $46, X Y$ \\
\hline 40 & 31 & 5 & 0 & $\begin{array}{l}\text { Severe } \\
\text { HSG } \\
\text { SGA }\end{array}$ & $\begin{array}{l}\text { DYF51S1 } \\
\text { DYS237 } \\
\text { DYS236 } \\
\text { DAZ } \\
\text { DYS240 }\end{array}$ & 7.7 & 3.3 & 18.7 & $46, X Y$ \\
\hline
\end{tabular}

Note. HSG: hypospermatogenesis; SGA: spermatogenic arrest.

the Y chromosome microdeletions cannot be identified at present on the basis of clinical findings.

According to our experiments, we found the deletions of $\mathrm{AZFc}+\mathrm{AZFd}$ were present in 3 with azoospermia and 1 with severe oligospermia while the region in AZFd (DYS237) existed in 4 oligospermia men. Microdeletion in Yq including locations and incidence for Chinese males were the same as reported previously despite racial and geographical differences $(7,8,9)$.

Although in some cases there is absolutely no clear association between the location of the deletions and a distinct phenotype, still some generalizations can be drawn with regard to the relationships of the deletions to infertility phenotypes. Deletions in AZFa were associated with sertoli cell only syndrome $(75 \%)$ or partial spermatogenesis arrest (25\%), while in AZFb and AZFc with azoospermia or oligospermia, in AZFd with abnormal sperm morphology for some patients.

Among several candidate genes involved in infertility, the DAZ gene cluster localized in the distal Y chromosome is the most important one compared with others. Lacing the DAZ gene cluster caused sterility via meiotic arrest or absence of all germ cells. The functions of DAZ gene clusters may be related to binding RNA or regulating spermatogenesis at the different stages. Kostiner reported that $6-13 \%$ of men with oligo- or azoosperma have deletions in all or most DAZ gene clusters (2). Our study demonstrated these findings that three infertile men with azoospermia and one severe oligospermia showed DAZ dele- tions, while the other four with mild oligospermia lacked only AZFd (DYS237). Interestingly, the former four also showed deletions in AZFd (DYF51S1 + DYS237 + DYS236) and AZFc (DYS240).

Kobayashi discovered that the gene between DYS226 and DYS247 is essential for spermatogenesis (10). In addition, the deletions in AZFd region were common events described also by Oliva et al. (5) and Kent-First et al. (9). Our results support these points of view and no deletion in AZFa and AZFb regions were found, which is similar to the reports by Stuppia et al. also (7). No deletions of AZFa and AZFb were found, which is probably due to the local repetitive DNA blocks enriched in distal Yq11.

Considering the present studies on microdeletions of Yq, we understand that deletions were partially

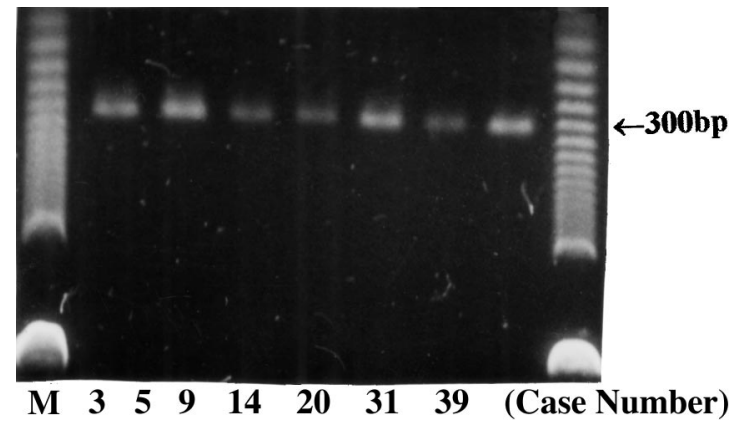

Fig. 4. Results of PCR amplification of SRY gene in 7 of 50 infertile men; SRY gene presented in all 50 cases. $M$ is a marker of the $50 \mathrm{bp}$ DNA step ladder. 
identified in idiopathic infertile men and the same deletion can cause different phenotypes. The frequency of the deletions is between the ranges of 9$30 \%$, the position and the size of the deletions are probably associated with the severity of spermatogenesis failure. Most of the Y chromosome deletions can be inherited from father to son and cause infertility. Chang (6) reported a family with similar DAZ deletions in a father and his four infertile sons. In general the deletions of $\mathrm{Yq}$ in men with azoospermia or oligospermia cannot be transmitted to their sons unless ICSI was performed or testicular sperm aspiration (TESA) combined with ICSI to produce offsprings. Kent-First demonstrated these results by testing ICSI sons of 32 infertile fathers and found in three affected father/son pairs deletion regions in $\mathrm{AZFb}$ and $\mathrm{AZFc}$ with different size were involved (5).

According to these findings, we agree that before ICSI is performed, it is necessary to have genetic counseling, cytogenetic karyotyping analysis, and screen microdeletions of the $\mathrm{Y}$ chromosome for idiopathic infertile men with oligo- or azoospermia. In the future we also have to develop safe and reliable methods to help those populations to produce female offsprings to avoid passing $\mathrm{Y}$ chromosome microdeletion to their male children.

\section{ACKNOWLDGMENTS}

We thank the Promega Company for supplying the Y Chromosome Deletion Detection System (Version 1.1), and Wizard Genomic DNA Purification Kit. We also thank Professor LiZhu Zhang for revising English version of this paper.

\section{REFERENCES}

1. Tiepolo L, Zuffardi O: Localization of factors controlling spermatogenesis in the nonfluorescent portion of the human $\mathrm{Y}$ chromosome long arm. Hum Genet 1976;34:119-124

2. Kostiner DR, Turek PJ, Reijo RA: Male infertility: Analysis of the markers and genes on the human Y chromosome. Hum Reprod 1998;13:3032-3038

3. Kent-First MG, Muallem A, Shultz J, Pryor J, Roberts K, Nolten W, McIsner L, Chandley A, Gouchy G, Jorgensen L, Havighurst T, Grosch J: Defining regions of the Y-chromosome responsible for male infertility and identification of a fourth AZF region (AZFd) by chromosome microdeletion detection. Mol Reprod Dev 1999;53(1):27-41

4. Palermo G, Joris H, Devroey P, Van Steirteghem AC: Pregnancies after intracytoplasmic injection of single spermatozoon into an oocyte. Lancet 1992;340:17-18

5. Kent-First MG, Kol S, Muallem A, Ofir R, Manor D, Blazer $\mathrm{S}$, First N, Itskovitz-Eldor J: The incidence and possible relevance of Y-linked micro-deletion in babies born after intracytoplasmic sperm injuction and their infertile fathers. Mol Hum Reprod 1966;2:943-950

6. Chang PL, Sauer MV, Brown S: Y chromosome microdeletion in a father and his four infertile sons. Hum Reprod 1999;14:2689-2694

7. Stuppia L, Mastroprimiano G, Calabrese G, Peila R, Tenaglia R, Palka G: Micro deletions in interval 6 of the Y chromosome detected by STS-PCR in 6 of 33 patient with idiopathic oligo or azoospermia. Cytogenet Cell Genet 1996;72:155-158

8. Voget PH: Human chromosome deletion in Yq11, AZF candidate genes and male infertility: History and update. Mol Hum Reprod 1998;4:739-744

9. Oliva R, Margarit E, Ballesca JL, Carrió A, Sánchez A, Milà M, Jiménez L, Alvarez-Vijande JR, Ballesta F: Prevalence of Y chromosome micro-deletion in oligospermic and azoospermic candidates for intracytoplasmic sperm injection. Fertil Steril 1998;70:506-510

10. Kobayashi K, Mizuno K, Hida A, Komaki R, Tomita K, Matsushita I, Namiki M, Iwamoto T, Tamura S, Minowada S: PCR analysis of the Y chromosome long arm in azoospermic patients: Evidence for a second locus required for spermatogenesis. Hum Mol Genet 1994:3:1965-1967 